\title{
Bloqueio do Plexo Braquial, por Via Infraclavicular Vertical, em Paciente com Doença Pulmonar Obstrutiva Crônica. Relato de Caso*
}

\author{
Infraclavicular Vertical Brachial Plexus Blockade in Patients with \\ Chronic Obstructive Pulmonary Disease. Case Report
}

\author{
Diogo Brüggemann da Conceição; ${ }^{1}$ Pablo Escovedo Helayel, TSA ${ }^{1}$; Fernanda Cecato ${ }^{2}$
}

\section{RESUMO}

Conceição DB, Helayel PE, Cecato F — Bloqueio do Plexo Braquial, por Via Infraclavicular Vertical, em Paciente com Doença Pulmonar Obstrutiva Crônica. Relato de Caso.

JUSTIFICATIVA E OBJETIVOS: Os pacientes com doença pulmonar obstrutiva crônica (DPOC) têm risco aumentado de complicações pós-operatórias, sobretudo quando submetidos à anestesia geral. O bloqueio do plexo braquial representa uma alternativa para estes pacientes em intervenções cirúrgicas de membros superiores. O objetivo deste relato foi apresentar um caso de bloqueio do plexo braquial, por via infraclavicular vertical em paciente com DPOC com fratura de cotovelo.

RELATO DO CASO: Paciente do sexo feminino, 67 anos, $52 \mathrm{~kg}$, estado físico ASA III, com indicação de osteossíntese de cotovelo, portadora de bronquiectasias desde nove anos de idade após uma pneumonia. Apresentava tosse produtiva habitualmente, e fora submetida à avaliação de seu pneumologista que a liberou para o procedimento. Após instalação de monitorização com pressão arterial não-invasiva, ECG e oxímetro de pulso, foi realizado bloqueio do plexo braquial por via infraclavicular vertical com $30 \mathrm{~mL}$ de ropivacaína a $0,5 \%$. A intervenção cirúrgica foi realizada sem intercorrências. A paciente recebeu alta hospitalar no dia seguinte ao procedimento cirúrgico.

CONCLUSÕES: O bloqueio do plexo braquial por via infraclavicular vertical é uma técnica alternativa para portadores de DPOC e fratura de cotovelo, por sua menor morbidade quando comparado com a anestesia geral e com a via supraclavicular

Unitermos: CIRURGIA, Ortopédica: osteossíntese de cotovelo; TÉCNICAS ANESTÉSICAS, Regional: bloqueio do plexo braquial.

${ }^{*}$ Recebido do (Received from) Núcleo de Ensino e Pesquisa em Anestesia Regional do Hospital Governador Celso Ramos, CET Integrado de Anestesiologia da SES - SC, Florianópolis, SC

1. Anestesiologista do CET Integrado de Anestesiologia da SES-SC. Membro do Núcleo de Ensino e Pesquisa em Anestesia Regional do HGCR

2. $\mathrm{ME}_{3}$ do CET Integrado de Anestesiologia da SES-SC

Apresentado (Submitted) em 09 de novembro de 2005

Aceito (Accepted) para publicação em 21 de junho de 2006

Endereço para correspondência (Correspondence to):

Dr. Diogo Brüggemann da Conceição

Rua Germano Wendhausen, 32/401

88015-460 Florianópolis, SC

E-mail: diconceicao@hotmail.com

๑) Sociedade Brasileira de Anestesiologia, 2006

\section{SUMMARY}

Conceição DB, Helayel PE, Cecato F - Infraventricular Vertical Brachial Plexus Blockade in Patients with Chronic Obstructive Pulmonary Disease. Case Report.

BACKGROUND AND OBJECTIVES: Patients with Chronic Obstructive Pulmonary Disease (COPD) have a higher risk of postoperative complications, especially when undergoing general anesthesia. Brachial plexus blockade is an alternative for these patients when they undergo upper limb surgeries. The objective of this report is to present a case of infraclavicular brachial plexus blockade in patients with COPD and a fractured elbow.

CASE REPORT: A female patient, 67 years old, $52 \mathrm{~kg}$, physical status ASA III, with post-pneumonia bronchiectasis since nine years of age and an indication of osteosynthesis of the elbow. She presented productive cough regularly; after evaluation, her pneumologist cleared her for the surgery. The patient was monitored with non-invasive blood pressure. ECG, and pulse oximeter. Infraclavicular brachial plexus blockade with $0.5 \%$ ropivacaine $30 \mathrm{~mL}$ was performed, without intercurrences. The patient was discharged from the hospital the following day.

CONCLUSIONS: Infraclavicular brachial plexus blockade is an alternative for patients with COPD and fracture of the elbow, due to its lower morbidity when compared to general anesthetic.

Key Words: ANESTHETIC TECHNIQUES, Regional: brachial plexus blockade; SURGERY, Orthopedic: osteosynthesis.

\section{INTRODUÇÃO}

$\mathrm{O}$ s pacientes com doença pulmonar obstrutiva crônica (DPOC) têm risco aumentado de complicações pósoperatórias, sobretudo quando submetidos à anestesia geral $^{1}$. A anestesia regional representa uma alternativa nesses pacientes.

As fraturas de cotovelo são um desafio na prática da anestesia regional por sua complexa inervação. Com freqüência, indicam-se bloqueios supraclaviculares ou uma combinação de bloqueios por vias axilar e interescalênica para anestesia completa desta região, porém, com alta incidência de bloqueio do nervo frênico e risco de pneumotórax. O objetivo deste relato foi apresentar um caso de bloqueio do plexo braquial por via infraclavicular vertical em paciente com DPOC e fratura de cotovelo. 


\section{RELATO DO CASO}

Paciente do sexo feminino, 67 anos, $52 \mathrm{~kg}, 1,60 \mathrm{~m}$, estado físico ASA III, com fratura de cotovelo e indicação de osteossíntese de cotovelo.

$\mathrm{Na}$ avaliação pré-anestésica a paciente referiu ter tosse produtiva desde os 9 anos de idade, após pneumonia, sendo usuária crônica de corticosteróide, de agonista $\beta_{2}{ }^{-}$ adrenérgico e de antidepressivo. Ao exame físico a paciente apresentava-se com tiragem supraclavicular, dispnéica, com diminuição do murmúrio vesicular e estertores esparsos. Os exames laboratoriais não apresentavam alterações, tomografia computadorizada de tórax mostrava bronquiectasias e a espirometria indicava distúrbio obstrutivo moderado. A avaliação do pneumologista considerou a paciente compensada e apta para a realização do procedimento.

Após instalação da monitorização (cardioscópio, pressão arterial não-invasiva e oxímetro de pulso) e sedação com diazepam $(5 \mathrm{mg}$ ), foi realizado o bloqueio de plexo braquial, por via infraclavicular vertical como descrito por Kilka e col. ${ }^{2}$. Para a realização do bloqueio a paciente foi colocada na posição supina, com a cabeça voltada para o lado oposto ao da fratura e o antebraço sobre o abdômen. Uma linha foi traçada entre o ramo ventral do acrômio e a fossa jugular. No ponto médio dessa linha foi realizada, após um botão dérmico de anestésico local, uma punção perpendicular à superfície da mesa cirúrgica logo abaixo da clavícula com o auxílio de uma agulha de $50 \mathrm{~mm}$, eletricamente isolada e conectada a um estimulador de nervo periférico (Stimuplex dig RC B. Braun) (Figura 1). Após estímulo do nervo mediano, $30 \mathrm{~mL}$ de ropivacaína a $0,5 \%$ foram injetados. A interven-

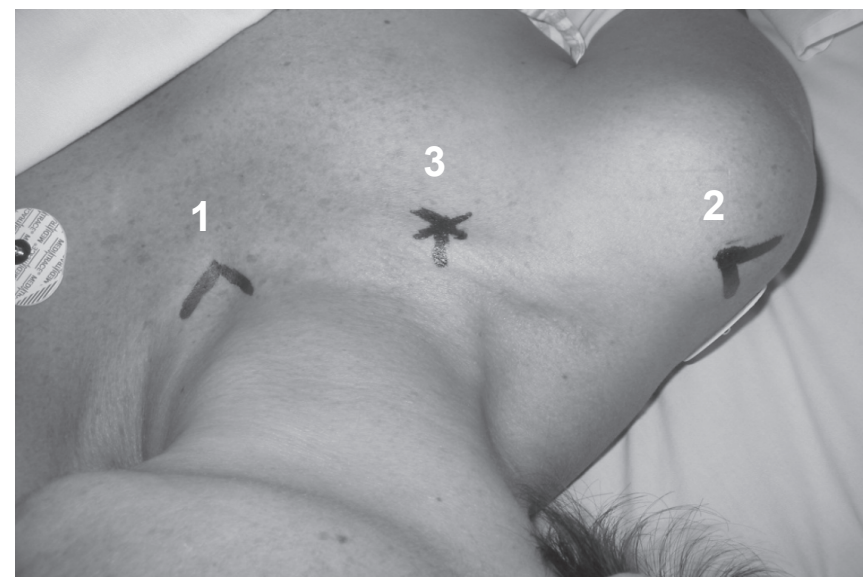

Figura 1 - Referências Anatômicas do Bloqueio de Plexo Braquial por Via Infraclavicular Vertical. 1) fossa jugular; 2) ramo ventral do acrômio; 3) ponto de punção ção cirúrgica foi realizada sem intercorrências. A paciente recebeu alta hospitalar no dia seguinte.

\section{DISCUSSÃO}

Algumas vantagens são atribuídas à anestesia regional quando comparada com a anestesia geral para intervenções cirúrgicas no membro superior, sobretudo em pacientes com DPOC ${ }^{1,4}$. A via escolhida para o bloqueio do plexo braquial é determinada pela inervação do local a ser operado, pela experiência do anestesiologista e pelos possíveis riscos de complicação.

As intervenções cirúrgicas sobre o cotovelo necessitam de anestesia dos nervos cutâneos do braço (cutâneo medial do braço, cutâneo lateral do braço e cutâneo posterior do braço). Esses nervos emergem e deixam o compartimento neurovascular no nível dos fascículos.

Historicamente, a via supraclavicular é considerada o acesso mais eficaz para bloqueio do plexo braquial em intervenções cirúrgicas sobre o cotovelo. Anestesia completa do braço e antebraço é alcançada com injeção de volume relativamente pequeno de anestésico local. Entretanto, os riscos de complicações pulmonares perioperatórias tornam a via supraclavicular contra-indicada para pacientes com doença pulmonar. Paralisia temporária do nervo frênico ocorre em até $50 \%$ dos pacientes, enquanto $0,5 \%$ a $6 \%$ deles desenvolvem pneumotórax após o bloqueio do plexo braquial, por via supraclavicular.

A via interescalênica também pode ser usada para esses procedimentos; entretanto, em geral não se obtém anestesia completa do nervo ulnar. Essa via também não está indicada em pacientes que dependem da função diafragmática intacta, pois o nervo frênico ipsilateral é bloqueado em $100 \%$ dos casos ${ }^{5}$.

Kilka e col. ${ }^{2}$ descreveram, após estudos em cadáveres, a técnica de bloqueio do plexo braquial por via infraclavicular vertical. Essa técnica bloqueia o plexo braquial no início da formação dos fascículos, atingindo todos os nervos do membro superior. São vantagens dessa abordagem um resultado semelhante ao da abordagem supraclavicular com menor risco de pneumotórax (menor que 1\%) e baixa incidência de bloqueio do nervo frênico.

Neuburger e col. ${ }^{3}$ realizaram um estudo com ressonância magnética em voluntários e concluíram que o bloqueio por via infraclavicular vertical, se realizado com a técnica correta, é seguro quanto ao risco de pneumotórax. Na literatura pesquisada foi encontrado apenas um relato de caso de paralisia do nervo frênico após o bloqueio infraclavicular vertical ${ }^{6}$, entretanto a sua exata incidência ainda não foi determinada. A avaliação individualizada da relação entre risco e benefício de cada técnica anestésica pode diminuir as complicações em pacientes de alto risco. 


\section{Infraclavicular Vertical Brachial Plexus Blockade in Patients with Chronic Obs- tructive Pulmonary Disease. Case Report}

\author{
Diogo Brüggemann da Conceição, M.D.; Pablo Escovedo
} Helayel, TSA, M.D.; Fernanda Cecato, M.D.

\section{INTRODUCTION}

Patients with chronic obstructive pulmonary disease (COPD) have a higher risk of postoperative complications, especially when undergoing general anesthesia ${ }^{1}$. Regional anesthesia is an alternative for these patients.

Elbow fractures are a challenge for regional anesthesia due to the complex innervation of this region. Supraclavicular or combination, by the axillary and interscalene approaches, blocks for complete anesthesia of this region are frequently indicated. However, these approaches present a high incidence of phrenic nerve block and risk of pneumothorax.

The objective of this report is to present a case of infraclavicular vertical brachial plexus blockade in a patient with COPD and fractured elbow.

\section{CASE REPORT}

A female patient, 67 years old, $52 \mathrm{~kg}, 1.60 \mathrm{~m}$, physical status ASA III, with an indication of osteosynthesis for a fractured elbow.

During the preanesthetic evaluation, the patient complained of productive cough since 9 years of age, after an episode of pneumonia, being a long-time user of corticosteroid, $\beta_{2}$ adrenergic agonist, and antidepressant. On physical exam, the patient showed supraclavicular pulling, dyspnea, decreased breath sounds, and scattered rales. Laboratory tests did not show any changes; CT scan of the chest demonstrated brionchiectasis; lung function tests were consistent with moderate obstructive disturb. The pneumologist considered the patient fit to undergo the surgical procedure. After the cardioscope, non-invasive blood pressure, and pulse oximeter were placed and the patient was sedated with diazepam (5 mg); infraclavicular vertical brachial plexus blockade was performed, as described by Kilka et al. ${ }^{2}$. The patient was placed in the supine position, head turned to the contralateral side of the fracture, with the forearm placed on the abdome. A line was drawn from the ventral arm of the acromion to the jugular fossa. After anesthetizing the skin of the midpoint of this line, a $50 \mathrm{~mm}$ needle, isolated electrically and connected with a peripheral nerve stimulator (Stimuplex $\operatorname{dig}$ RC B. Braun), was introduced perpendicularly to the surgical table (Figure 1). After stimulating the median nerve, $30 \mathrm{~mL}$ of $0.5 \%$ ropivacaine were injected. The surgical procedure was performed without intercurrences. The patient was discharged from the hospital the following day.

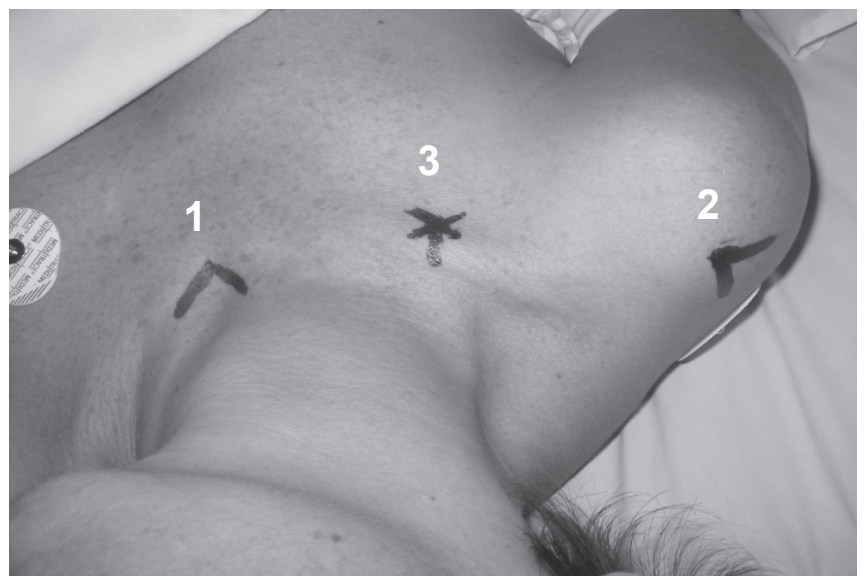

Figure 1 - Anatomical References of the Infraclavicular Vertical Brachial Plexus Blockade. 1) jugular fossa; 2) ventral region of the acromion; 3) puncture site.

\section{DISCUSION}

Some advantages are attributed to regional anesthesia when compared to general anesthesia, for surgeries of the upper limb, especially in patients with COPD ${ }^{1,4}$. The route chosen for the anesthesia is determined by the innervation of the place to be operated, by the experience of the anesthesiologist, and by the possible complications.

Cutaneous nerves of the arm (medial brachial cutaneous, lateral brachial cutaneous, and posterior brachial cutaneous) have to be anesthetized in surgical interventions of the elbow. These nerves leave the neurovascular compartment at the level of the fascicles.

Historically, the supraclavicular approach is considered the most effective one for brachial plexus blockade in surgery of the elbow. A complete anesthesia of the arm and forearm is accomplished with the injection of a relatively small volume of local anesthetic. However, the risks of pulmonary complication in the perioperative period make the supraclavicular approach contraindicated in patients with pulmonary disease. There is temporary paralysis of the phrenic nerve in $50 \%$ of the patients, while pneumothorax occurs in $5 \%$ to $6 \%$ of the patients after supraclavicular brachial plexus blockade.

The interscalene approach can also be used for these procedures; however, in general it does not produce total anesthesia of the ulnar nerve. This approach is also not indicated in patients who depend on the diaphragmatic function, since there the ipsilateral phrenic nerve is blocked in $100 \%$ of the cases ${ }^{5}$.

Kilka et al. ${ }^{2}$ described, after studies in cadavers, the infraclavicular vertical brachial plexus blockade. This technique blocks the brachial plexus in the beginning of the fascicle, reaching every nerve in the upper limb. The advantages of this approach include lower risk of pneumothorax (less than $1 \%$ ) and low incidence of phrenic nerve block. 
Neuburger et al. ${ }^{3}$ concluded, after MRI in volunteers, that the infraclavicular vertical block, if performed with the right technique, is safe, as far as the risk of pneumothorax is concerned. We found only one report in the literature of phrenic nerve paralysis after infraclavicular vertical brachial plexus blockade ${ }^{6}$; however, its precise incidence has yet to be determined.

Individualized evaluation regarding the risk-benefit ratio of each technique can decrease complications in high-risk patients.

\section{REFERÊNCIAS - REFERENCES}

01. Wong DH, Weber EC, Schell MJ et al - Factors associated with postoperative pulmonary complications in patients with severe chronic obstructive pulmonary disease. Anesth Analg, 1995; 80:276-284.

02. Kilka HG, Geiger P, Mehrkens HH - Infraclavicular vertical brachial plexus blockade. A new method for anesthesia of the upper extremity. An anatomical and clinical study. Anaesthesist, 1995;44:339-344.

03. Neuburger M, Kaiser $\mathrm{H}$, Uhl M - Biometric data on risk of pneumothorax from vertical infraclavicular brachial plexus block (VIP). A magnetic resonance imaging study. Anaesthesist, 2001;50:511-516.

04. Brown AR, Parker GC - The use of a "reverse" axis (axillaryinterscalene) block in a patient presenting with fractures of left shoulder and elbow. Anesth Analg, 2001;93:1618-1620.

05. Urmey WF, McDonald M - Hemidiaphragmatic paresis during interscalene brachial plexus block: effects on pulmonary function and chest wall mechanics. Anesth Analg, 1992;74:352-357.

06. Stadlmeyer W, Neubauer J, Finkl RO et al - Unilateral phrenic nerve paralysis after vertical infraclavicular plexus block. Anaesthesist, 2000;49:1030-1033.

07. Gusmão LCB, Lima JSB, Prates JC - Bases anatômicas para o bloqueio anestésico do plexo braquial por via infraclavicular. Rev Bras Anestesiol, 2002;52:348-353.

\section{RESUMEN}

Conceição DB, Helayel PE, Cecato F — Bloqueo del Plexo Braquial, por Vía Infraclavicular Vertical, en Paciente con Enfermedad Pulmonar Obstructiva Crónica. Relato de Caso.

JUSTIFICATIVA Y OBJETIVOS: Los pacientes con enfermedad pulmonar obstructiva crónica (DPOC) presentan riesgo mayor de complicaciones postoperatorias especialmente cuando se les someten a la anestesia general. El bloqueo del plexo braquial representa una alternativa para esos pacientes en intervenciones quirúrgicas de miembros superiores. El objetivo de este relato fue el de presentar un caso de bloqueo del plexo braquial, por vía infraclavicular vertical en paciente con DPOC con fractura de codo.

RELATO DEL CASO: Paciente del sexo femenino, 67 años, 52 kg, estado físico ASA III, con indicación de osteosíntesis de codo, portadora de bronquiectasias desde los nueve años de edad después de una pneumonía. Presentaba una tos productiva habitualmente, y fue sometida a la evaluación de su neumólogo que la liberó para el procedimiento. Después de la instalación de monitorización con presión arterial no invasiva, ECG y oxímetro de pulso, se realizó un bloqueo del plexo braquial por vía infraclavicular vertical con $30 \mathrm{~mL}$ de ropivacaína a $0,5 \%$. La intervención quirúrgica fue realizada sin incidencias. La paciente recibió alta hospitalaria al día siguiente del procedimiento quirúrgico.

CONCLUSIONES: El bloqueo del plexo braquial por vía infraclavicular vertical es una alternativa técnica para portadores de DPOC y fractura de codo, por su menor morbidez cuando se le compara a la anestesia general y a su vía supraclavicular. 